\title{
EVALUASI KEBIJAKAN PEMASANGAN BANNER DAN PAPAN REKLAME ILEGAL YANG MEMPENGARUHI KEINDAHAN KOTA MALANG
}

\author{
Abdul Haris Nur Sugeng1, Retno Wulan Sekarsari² \\ ${ }_{1}^{1}$ Universitas Islam Malang \\ email: faizalmstpa@gmail.com \\ ${ }^{2}$ Universitas Islam Malang \\ email: sekarsari@unisma.ac.id
}

\begin{abstract}
ABSTRAK
Penelitian ini membahas tentang strategi-strategi pemerintah Kota Malang dalam penertiban pemasangan banner dan reklame ilegal disepanjang jalan Sukarno Hatta sampai Jalan Tlogomas dan optimalisasi pemerintah Kota Malang dalam penertiban terhadap pemasangan banner dan reklameilegal disepanjang Jalan Sukarno Hatta sampai Jalan Tlogomas. Tujuan Penelitian untuk mengetahui bagaimana strategi-strategi pemerintah Kota Malang dalam penertiban pemasangan banner dan reklame ilegal disepanjang Jalan Sukarno Hatta sampai Jalan Tlogomas dan untuk mengetahui bagaimana optimalisasi pemerintah Kota Malang dalam pengawasan dan penertiban terhadap pemasangan banner dan reklame ilegal disepanjang Jalan Sukarno Hatta sampai Jalan Tlogomas. Dalam penelitian ini, peneliti menggunakan jenis penelitian deskriptif - kualitatif. Hybert Hyman dalam Koentjaraningrat (1991:29) mengartikan jenis penelitian yang bersifat deskriptif adalah penelitian yang bersifat deskriptif adalah penelitian yang mempunyai tujuan untuk menggambarkan secara tepat tentang sifat-sifat suatu individu, keadaan, gejala, atau kelompok-kelompok tertentu atau untuk menentukan frekuensi adanya hubungan tertentu antara suatu gejala atau frekuensi adanya hubungan tertentu antara suatu gejala dengan gejala lain di masyarakat. Sedangkan metode penelitian kualitatif sesuai dengan yang dikemukakan oleh Bogdan dan Taylor dalam Moleong (2002:3) bahwa metode kualitatif didefinisikan sebagai prosedur penelitian yang menghasilkan data deskriptif berupa kata-kata tertulis atau lisan dari orangorang dan perilaku yang dapat diamati. Pemasangan papan reklame, sebetulnya sudah ada mekanismenya, seperti papan reklame harus dipasang pada tempat yang memang tidak mengganggu kepentingan publik seperti di trotoar. Bila ada pemasangan reklame tidak pada tempatnya, kewajiban petugas Tramtib di kecamatan dan kelurahan untuk melarangnya dan mengarahkan pemasangan reklame sesuai ketentuan yang berlaku. Apabila pemasangan papan reklame tidak pada tempatnya, berdampak besar terhadap terganggunya keamanan dan kenyaman publik serta keindahan daerah. Bukan saja dilarang pasang di trotoar, konstruksi papan reklame juga harus melihat segi keamanan dan kenyamanan, janganjangan suatu ketika tiba-tiba reklamenya roboh hingga menimbulkan korban bagi orang lain. Maka diperlukan penegakan hukum agar tercapai ketertiban dan kepatuhan terhadap peraturan dalam perizinan reklame.Selain untuk pembinaan, pengaturan, pengendalian dan pengawasan serta penegakan hukum dan dampak negatif dari pemberian izin dalam rangka melindungi kepentingan umum dan menjaga kelestarian lingkungan, maka perlu dilakukan pengaturan tentang Retribusi Izin Pemasangan Reklame.Bagi Pemerintah, dalam hal ini Pemerintah Daerah, reklame merupakan salah sumber APBD, dimana pelaku usaha yang berkepentingan terhadap pemasangan iklan tersebut membayar pajak dalam jumlah tertentu untuk pemasangan reklame dalam durasi tertentu di wilayah-wilayah strategis Kabupaten/Kotamadya.
\end{abstract}

Kata Kunci: banner, kebijakan, papan, reklame 


\section{PENDAHULUAN}

\section{Latar Belakang}

Kebijakan merupakan rangkaian konsep dan asas yang menjadi pedoman dan dasar rencana dalam pelaksanaan suatu pekerjaan, kepemimpinan, dan cara bertindak. Kebijakan biasanya diterapkan didalam Pemerintahan, organisasi, dan kelompok swasta, serta individu. ${ }^{1}$ Kebijakan dibentuk hanya untuk menjadi pedoman tindakan yang paling mungkin memperoleh hasil yang diinginkan. Biasanya, kebijakan merujuk pada proses pembuatan keputusan-keputusan penting dari Pemerintahan, organisasi, dan lain-lain seperti yang sudah disebutkan tadi.

Salah satu kebijakan yang hangat diperbincangkan adalah kebijakan pemasangan banner dan reklame. Reklame disini berarti iklan yang berada di luar ruangan seperti baliho besar yang berisikan tentang iklan-iklan segala penawaran.Di KotaMalang misalkan, banyak banner dan reklame yang berdiri memenuhi Kota Malangyang sejuk ini.Bisa dilihat bahwa pemasangan banner dan reklame di Kota Malang masih terbilang kurang rapi dan memakan tempat yang besar. Tepatnya disepanjang jalan Sukarno-Hatta sampai jalan tlogomas masih banyak baliho dan reklame yang melanggar hukum.Hal ini mengakibatkan Kota Malang menjadi "surganya" penempatan banner dan reklame baik yang sudah berizin maupun ilegal. Tidak hanya banner dan reklame yang berupa iklan saja yang memenuhi badan Kota Malang, tetapi juga banner dan reklame yang berbentuk papan nama dari sebuah kantor atau tempat belanja. Banyak dari pemasangan banner dan reklamenya masih menghiraukan kerapian dan izin yang sudah dibuat oleh Pemerintah setempat, yaitu kebijakan yang mengatur tentang banner dan reklame. Hal tersebut tidak semata-mata tanggung jawab dari biro iklan saja, tetapi juga dikarenakan kebijaksanaan yang ada saat ini kurang sesuai atau kurang memadai dalam menghadapi pertumbuhan Kota Malang.

Permasalahan yang lain adalah persaingan usaha yang begitu ketat dari suatu instansi dan sejenisnya membuat mereka berlomba-lomba untuk memasang iklan diluar ruangan. Hal ini dikarenakan mereka menginginkan usaha mereka menjadi bintang dan mendominasi di lingkup masyarakat luas. Permasalahan ini mengakibatkan banyaknya banner dan reklame seperti papan nama toko, baliho, spanduk, dan lain-lain terpasang dan menghiraukan kerapian dan keindahan Kota Malang. Bahkan tak sedikit iklan yang terpasang di luar ruangan tersebut memakan tempat hingga menjorok ke jalan raya dan bahkan banyak spanduk yang melintang di atas jalan raya. Tak pelak jika pemasangan spanduk tersebut membuat mata terganggu ketika ingin menikmati suasana Kota Malang.Perlu adanya kebijakan yang jelas terkait masalah ini agar masalah pemasangan reklame di Kota Malang menjadi lebih tertata dan tidak mengganggu pemandangan Kota Dingin tersebut.

Kurangnya kesadaran masyarakat dalam pemasangan banner dan reklame tersebut sehingga dalam setiap sudut kota akan terisi penuh dengan berbagai macam banner dan reklame entah itu legal atau ilegal yang dipasang di daerah yang seharusnya tidak boleh dipasangi banner dan reklame. Sangat banyak contoh yang ada di sekitar jalan sukarno hatta sampai jalan tlogomas, maka pemerintah Kota Malang dari tahun ke tahun sangat serius menghadapi berbagai macam banner dan reklame ilegal yang dapat memperburuk keindahan sekitar kota yang sejuk ini. Tidak hanya itu, pemerintah dibantu jajaran satpol PP Kota Malang dengan serius mulai menata kembali keindahan Kota Malang yang seperti dulu.

${ }^{1}$ Islamy, M. Irfan, Prinsip-prinsip Perumusan Kebijakan Negara, Bumi Aksara, Jakarta, 2009, Hlm. 17 
Saat ini, Perda yang mengatur tentang reklame adalah Perda No. 4 tahun 2006 tentang penyelenggaraan reklame. Reklame yang diatur terdiri dari reklame papan atau billboard, megatron, baliho, cahaya, kain, stiker, selebaran, berjalan termasuk di kendaraan, udara, suara, film atau slide, dan peragaan. ${ }^{2}$ Awalnya Perda ini belum bisa mengatur tentang wall painting promotion.Namun sekarang, menurut BPPD Kota Malang bahwa wall painting promotion ini sudah dimasukkan dalam kategori reklame papan atau billboard non cahaya.Hingga pertengahan tahun 2013 lalu, belum ada aturan yang mengatur tempat mana sajakah yang dilarang atau diperbolehkan untuk dibuat wall painting promotion. Padahal, reklame jenis itu sering dijumpai di berbagai tembok rumah, kantor, dan lain-lain. Fokus dari BPPD saat ini yaitu meningkatkan pendapatan daerah dan mewujudkan penyelenggaraaan pemerintah sesuai dengan dasar hukum perda nomor 6 tahun 2012 tentang organisasi dan tata kerja dinas daerah.

\section{Rumusan Masalah}

a. Bagaimana Strategi-Strategi pemerintah Kota Malang dalam penertiban pemasangan banner dan reklame ilegal disepanjang Jalan Sukarno Hatta sampai Jalan Tlogomas?

b. Bagaimana optimalisasi pemerintah Kota Malang dalam penertiban terhadap pemasangan banner dan reklame ilegal disepanjang Jalan Sukarno Hatta sampai Jalan Tlogomas?

\section{TINJAUAN PUSTAKA}

\section{Perencanaan Pembangunan Nasional}

Pada dasarnya perencanaan sebagai fungsi manajemen adalah proses pengambilan keputusan dari sejumlah pilihan, untuk mecapai suatu tujuan yang dikehendaki. Perencanaan pembangunan pada umumnya harus memiliki, mengetahui, dan memperhitungkan beberapa unsur pokok, yaitu :
a. Tujuan akhir yang ingin dicapai,
b. Sasaran-sasaran dan prioritas untuk merealisasikan tujuan akhir,
c. Jangka waktu yang diperlukan dalam mencapai sasaran-sasaran tersebut,
d. Masalah-masalah yang dihadapi,
e. Modal atau sumber daya yang akan digunakan, serta pengalokasiannya,
f. Kebijaksanaan-kebijaksanaan untuk merealisasikannya,
g. Orang, organisasi atau badan pelaksananya, dan
h. Mekasnisme pemantauan, evaluasi dan pengawasan pelaksanaan. ${ }^{3}$

Dalam hal ini yang dimaksud manajer adalah pimpinan Pemerintah Daerah dalam segala upaya pelaksaan dan ketertiban pemasangan banner dan reklame sesuai dengan perda Kota Malang nomor 4 tahun 2006. Dalam perencanaannya, pemerintah Kota Malang akan sangat tegas dalam mengimplementasikan perda tersebut dan jika pemerintah daerah Kota malang tidak sanggup atau dalam kata lain bisa disebut gagal maka Pemerintah Daerah Kota Malang dianggap tidak serius dalam menangani banner dan reklame ilegal yang sesuai dengan ketentuan Perda Kota Malang nomor 4 tahun 2006.

Segala upaya yang dilakukan oleh manajer atau pemerintah daerah harus dipikirkan dengan tepat dan cepat sehingga tidak ada lagi keterlambatan penerapan

\footnotetext{
${ }^{2}$ Pasal 1 ayat 7 Peraturan Daerah Kota Malang Nomor 4 Tahun 2006 Tentang Penyelenggaraan Reklame

${ }^{3}$ Affifuddin, pengantar administrasi pembangunan, alfabeta, Bandung, 2010, hlm 87-88
} 
perda Kota Malang nomor 4 tahun 2006. Perencanaan yang sesuai dengan tingkat kebijakan oleh manajerial bisa dikatakan dengan proses perencanaan yang berhasil. Tidak hanya itu, segala proses yang membuat lingkungan disekitar Kota Malang khususnya di jalan Sukarno Hatta sampai jalan Tlogomas tersebut adalah hak dan kewajiban sebagai personal manajer yang memang tugasnya mengatur semua yang dapat memberi banyak inovasi sehingga para masyarakat bisa menghargai seberapa baik para personal manajer dalam pemerintah daerah Kota Malang bekerja dengan baik.

\section{Kebijakan Publik}

Menurut Thomas R. Dye dalam Howlett dan Ramesh (2005:2), kebijakanpublik adalah adalah "segala yang dikerjakan pemerintah, mengapa merekamelakukan, dan perbedaan yang dihasilkannya (what government did, why they doit, and what differences it makes)". Dalam pemahaman bahwa "keputusan" termasuk juga ketika pemerintah memutuskan untuk "tidak memutuskan" atau memutuskan untuk "tidak mengurus" suatu isu, maka pemahaman inijuga merujuk pada definisi Thomas R. Dye dalam Tilaar dan Nugroho (2008:185) yang menyatakan bahwa kebijakan publik merupakan "segala sesuatu yang dikerjakan dan tidak dikerjakan oleh pemerintah". Senada dengan definisi Dye, George C. Edwards III dan Ira Sharkansky dalam Suwitri (2008: 9) juga menyatakan bahwa kebijakan publik merupakan:Apa yang dinyatakan dan dilakukan atau tidak dilakukan oleh pemerintahyang dapat ditetapkan dalam peraturan perundang-undangan atau dalam policy statement yang berbentuk pidatopidato dan wacana yang diungkapkan pejabatpolitik dan pejabat pemerintah yang segeraditindaklanjuti dengan program-program dan tindakan pemerintah. ${ }^{4}$ Kedua definisi baik dari Dye dan Edwards III dan Sharkansky sama-sama menyetujui bahwa kebijakan publik juga termasuk juga dalam hal "keputusan untuk tidak melakukan tindakan apapun". Suwitri (2008: 11) memberi contoh bahwa keputusan pemerintah untuk menunda pelaksanaan Undang-Undang Anti Pornografi dan Pornoaksi sehingga dalam hal ini pemerintah tidak melakukan tindakan apapun untuk menjalankan Undang-Undang tersebut juga termasuk kebijakan publik.

\section{Peraturan Daerah Kota Malang Nomor 4 Tahun 2006 Tentang Penyelenggaraan Reklame}

Penjelasan atas peraturan daerah kota malang nomor 4 tahun 2006 tentang penyelenggaraan reklame. Bahwa dengan berkembangnya dunia usaha yang menghasilkan produk barang, akan berdampak pula terhadap pemasangan reklame. ${ }^{5}$ Pemasangan reklame selain berpotensi secara positif dalam arti apabila penataannya baik dan teratur dapat menciptakan keragaman yang indah sekaligus mendatangkan Pendapatan Asli Daerah (PAD), disisi lain berpotensi secara negatif dalam arti dapat menimbulkan ketidakteraturan atau bahkan beresiko bahaya bagi para pengguna jalan atau masyarakat lain. Bahwa Pemerintah Kota Malang sebagai Daerah Otonom yang memiliki kewenangan untuk perencanaan, pemasangan, pengawasan, pengendali dari pemilik reklame sesuai dengan Undang-Undang Nomor 32 Tahun 2004 tentang Pemerintahan Daerah sebagaimana telah diubah dengan Undang-Undang Nomor 8 Tahun 2005 tentang Penetapan Peraturan Pemerintah Pengganti Undang-Undang

\footnotetext{
${ }^{4}$ Islamy, M. Irfan, Prinsip-prinsip Perumusan Kebijakan Negara, Bumi Aksara, Jakarta, 2009, Hlm. 23
}

5Pasal 4 Peraturan Daerah Kota Malang Nomor 4 Tahun 2006 Tentang Penyelenggaraan Reklame 
Nomor 3 Tahun 2005menjadi UndangUndang juncto Peraturan Pemerintah Nomor 25 Tahun 2000 tentangKewenangan Pemerintah dan Kewenangan Propinsi sebagai Daerah Otonom,perlumemberikan pedoman dalam rangka Penyelenggaraan Reklame ke dalam PeraturanDaerah.

\section{Penataan Reklame}

Didalam perencanaan kota komperhensif, perancangan kota memiliki suatu makna yang khusus yang membedakannya dari berbagai aspek proses perencanaan kota. Perancangan kota berkaitan dengan tanggapan inderawi mausia terhadap lingkungan fisik kota: penampilan visual, kualitas estetika, dan karakter spasial. Konsep perancangan kota haruslah mengenali dan menunjang elemen-elemen visual utama kota dengan meningkatkan kualitas estetika (branch, 1996, h. 201-204). Pada studi penataan reklame ini, konsep perancangan kota menitik beratkan pada lingkungan fisik kota yang dinyatakan dengan penampilan visual kota yang ditandau dengan elemen penandaan pada koridor jalan utama kota. Menurut Muchsin dikutip dalam Mayasari (2007, hal. 34) untuk membangun suatu Kota maka perencanaan wilayah Kota harus meliputi 2 (dua) syarat utama agar penataan ruang dapat berjalan dengan efektif dan efisien, yaitu : Pertama, syarat Yuridis Bawa setiap perencanaan wilayah harus dilandaskan pada ketetapan yang telah dibuat dengan undang-undang dan Peraturan Pemerintah serta peraturan Daerah yang merupakan suatu peraturan perundang-undangan yang mengikat secara hukum. Kedua, syarat Teknis Setiap perencanaan wilayah kota harus memiliki syarat teknis antara lain lokasi yang akan didirikan bangunan tersebut sudah sesuai dengan peruntukannya.

Syarat pemasangan banner di reklame :

a. Surat keputusansebelumnya (apabilaperpanjangan), surat keputusan diterbitkan oleh dinas perpajakan yang akan langsung berkoordiansi dengan satpol PP Kota Malang.

b. Foto copy KTP yang masih berlaku, pihak pemasang banner dan reklame harus menyetorkan minimal 3 foto copy KTP penanggung jawab agar kelak jika terjadi sesuatu yang tidak diinginkan akan lebih mudah untuk mengurusinya

c. Denah lokasi pemasangan (titikkoordinat), titik koordinat yang dimaksud adalah titik-titik dimana pemasangan banner dan reklame yang tidak megganggu keindahan lingkungan sekitar sesuai dengan Perda Kota Malang tahun 2006 tentang penyelenggaraan reklame

d. Gambar konstruksi beserta detailnya, pemetaan gambar kontruksi harus disertakan dalam persyaratan ini karena sangat dibutuhkan ketika ada sesuatu yang tidak diinginkan terjadi dan apabila ada sesuatu yang terjadi akan memudahkan pihak satpol PP Kota Malang.

\section{METODE PENELITIAN}

\section{Jenis Penelitian}

Dalam penelitian ini, peneliti menggunakan jenis penelitian deskriptif kualitatif. Hybert Hyman dalam Koentjaraningrat (1991:29) mengartikan jenis penelitian yang bersifat deskriptif adalah penelitian yang bersifat deskriptif adalah penelitian yang mempunyai tujuan untuk menggambarkan secara tepat tentang sifatsifat suatu individu, keadaan, gejala, atau kelompok-kelompok tertentu atau untuk menentukan frekuensi adanya hubungan tertentu antara suatu gejala atau frekuensi adanya hubungan tertentu antara suatu gejala dengan gejala lain di masyarakat. Sedangkan metode penelitian kualitatif sesuai dengan yang dikemukakan oleh Bogdan 
dan Taylor dalam Moleong (2002:3) bahwa metode kualitatif didefinisikan sebagai prosedur penelitian yang menghasilkan data deskriptif berupa kata-kata tertulis atau lisan dari orang-orang dan perilaku yang dapat diamati. Metode penelitian kualitatif digunakan karena beberapa pertimbangan, mengacu pada pendapat Moleong (2002:5) adalah sebagai berikut:

a. Menyesuaikan metode kualitatif lebih mudah apabila berhadapan dengan kenyataan ganda.

b. Metode ini menyajikan secara langsung hakekat hubugan antara peneliti dan responden.

c. Metode ini lebih peka dan lebih dapat menyesuaikan diri dengan banyak penajaman pengaruh bersama terhadap pola-pola nilai yang dihadapi.

\section{Jenis dan Sumber Data}

a. Data Primer. Merupakan sumber data yang didapatkan dari sumber pertama. Data ini didapatkan dari wawancara secara langsung dengan pihak yang bersangkutan. Dalam hal ini yang dimaksud dengan pihak yang bersangkutan adalah instansi yang terkait, yaitu Satuan Polisi Pamong Praja Kota Malang.

b. Data Sekunder. Merupakan sumber data yang didapatkan dari bahan-bahan dokumentasi maupun literatur-literatur yang berkaitan dengan masalah penelitian. Data ini diperoleh dari bantuan orang lain. Misalnya dalam bentuk jurnal, arsip, maupun dokumen yang diperoleh dari orang lain. Selanjutnya, data-data yang penting yang berkaitan dengan penelitian ini, misalnya dokumen/arsip jumlah, masa berlaku banner dan papan reklame, dll dari Satuan Polisi Pamong Praja Kota Malang

\section{HASIL DAN PEMBAHASAN}

\section{Bagaimana Strategi-Strategi Pemerintah Kota Malang dalam Penertiban Pemasangan Banner dan Reklame Ilegal di Sepanjang Jalan Sukarno-Hatta Sampai Jalan Tlogomas.}

Banyaknya pelanggaran reklame yang terjadi terutama reklame-reklame insidentiil, membuat tidak terdatanya para pelanggar reklame tersebut.Hingga saat ini untuk pelanggaran reklame insidentil hanya sebatas ditertibkan dengan jumlah per hari yang banyak.Hal ini membuat seakan Satuan Polisi Pamong Praja berburu reklame yang dianggap melanggar tanpa dapat membuat efek jera terhadap para pelanggar reklame itu sendiri.

"Sudah ada penempatan tertentu untuk pemasangan reklame di kawasan Kota Malang, yakni terdapat di Perda Nomor 4 Tahun 2006 tentang Penyelenggaraan Reklame sudah ada titik yang bisa didirikan reklame."6

Sanksi adalah hukuman yang dijatuhkan kepada seseorang yang melanggar hukum.Hal ini merupakan bentuk perwujudan yang paling jelas dari kekuasaan negara dalam pelaksanaan kewajibannya untuk memaksakan ditaatinya hukum. Sedangkan sanksi dalam hukum administrasi adalah alat kekuasaan yang bersifat hukum publik yang dapat digunakan oleh pemerintah sebagia reaksi atas ketidakpatuhan terhadap kewajiban yang terdapat dalam norma hukum administrasi negara. ${ }^{7}$

Beberapa strategi Pemerintah Kota Malang dalam menertibkan banner dan reklame ilegal:

\footnotetext{
${ }^{6}$ wawancara dengan bapak Soegianto, S.Pd. selaku Kepala Bidang Penyidikan dan Penindakan Satpol PP Kota Malang

${ }^{7}$ Ridwan HR, Hukum Administrasi Negara, UII Press, Yogyakarta, 2002, hlm. 234
} 
a. Pengecekan dari proses pendaftaran

Dalam proses pengecekan ini, pemerintah Kota Malang berharap besar pada proses pendaftaran mulai dari izin kepolisian sampai dengan izin ke dinas perpajakan. Pemerintah Kota Malang sangat yakin dengan pengetatan ini akan meminimalisir banner dan reklame yang ada di Kota Malang terutama di sepanjang jalan Sukarno Hatta sampai jalan Tlogomas.

b. Penempatan banner dan reklame

Pemerintah sangat serius dalam hal ini dikarenakan pentaan tempat banner dan reklame sering disalah gunakan oleh beberapa oknus yang sengaja untuk tidak menempatkan banner dan reklame mereka di tempat yang sudah disediakan oleh Pemerintah Kota Malang.

c. Penindak tegas bagi yang melanggar aturan

Sesuai dengan perda Kota Malang nomor 4 tahun 2006 bahwasannya siapa saja yang meletakkan reklame tidak sesuai dengan izin awal maka pihak satpol PP bisa langsung mencopot reklame tersebut tanpa pemberitahuan sebelumnya.

d. Denda yang sangat mahal

Denda yang yang diberlakukan sesuai dengan perda Kota Malang yaitu sebesar Rp.3.000.000,00 atau penjara minimal 1 bulan bagi yang habis masa berlakunya dan Rp.5.000.000 atau penjara minimal 2,5 bulan bagi yang tidak mempuyai izin mulai dari awal pendirian reklame tersebut.

Tabel 1. Data Jenis Pelanggaran Reklame Berukuran Besar Yang Sering Ditertibkan

\section{No Jenis Pelanggaran}

1 Tidak ada izinnya

2 Salah tempat

\section{Data Lapangan}

Pihak Satuan Polisi Pamong Praja langsung mengambil tindakan represif dengan cara menyita reklame yang benar-benar secara nyata tidak mempunyai izin atau ilegal dan memusnahkannya Satuan Polisi Pamong Praja menyita reklame yang salah tempat, dan akan dimusnahkan 1 bulan kemudian apabila pihak pemasang reklame tidak memberikan konfirmasi

Sumber : Satuan Polisi Pamong Praja Kota Malang, 2018, diolah.

Pelanggaran reklame dengan ukuran yang besar berupa: reklame bando jalan, display board, billboard, reklame jembatan penyeberangan orang, reklame pagar pengaman fly over (jalan layang), reklame shop panel, reklame flag chain, reklame prismatek, reklame bus shelter dan reklame megatron/videotron, memerlukan penanganan khusus. Penertiban yang dilaksanakan Satuan Polisi Pamong Praja tidak mudah, dengan ukuran iklan yang besar dan terletak di wilayah yang ramai penduduk atau jalan raya dengan kepadatan lalu lintas tinggi, membutuhkan suatu peralatan khusus dan tenaga ekstra untuk menertibkannya.Berdasarkan definisi ini tampak ada empat unsur sanksi dalam hukum administrasi negara, yaitu alat kekuasaan (machtmiddelen), bersifat hukum publik (publiekrechtelijke), digunakan oleh pemerintah (overhead), sebagai reaksi atas ketidakpatuhan (reactive op niet naleving).

Di tinjau dari segi sasarannya, dalam hukum administrasi dikenal dua jenis sanksi, yaitu sanksi reparatoir (reparatoire sancties) dan sanksi punitive (punitive sancties). Sanksi reparatoir diartikan sebagai sanksi yang diterapkan sebagai reaksi atas pelanggaran norma, yang ditujukan unutk mengembalikan pada kondisi semula atau menempatkan pada situasi yang sesuai dengan hukum (legal situatie), dengan kata lain mengembalikan pada keadaan semula sebelum terjadinya pelanggaran. Sedangkan 
sanksi punitive adalah sanksi yang semata-mata ditujukan untuk memberikan hukuman (straffen) pada seseorang. Contoh dari sanksi reparatoir adalah paksaan pemerintah (bestuurdwang) dan pengenaan uang paksa (dwangsom), sedangkan contoh dari sanksi punitive adalah pengenaan denda administrasi (bestuurboete). ${ }^{8}$

Di samping dua jenis sanksi ini, ada sanksi lain yang oleh JBJM ten Berge disebut sebagai sanksi regresif (regressieve sancties), yaitu sanksi yang diterapkan sebagai reaksi atas ketidakpatuhan terhadap ketentuan-ketentuan yang terdapat pada ketetapan yang diterbitkan. ${ }^{9}$ Contoh dari sanksi regresif adalah penarikan, perubahan, dan penundaan suatu ketetapan (de intrekking, de wijziging, of de schorsing van een beschikking).Ditinjau dari segi tujuan diterapkannya sanksi, sanksi regresif ini sebenanya tidak begitu berbeda dengan sanksi reparatoir. Bedanya hanya terletak pada lingkup dikenakannya sanksi tersebut, sanksi reparatoir dikenakan terhadap pelanggaran norma hukum administrasisecara umum, sedangkan sanksi regresif hanya dikenakan terhadap pelanggaran ketentuan-ketentuan yang terdapat dalam ketetapan.

Penerapan sanksi secara bersama-sama antara hukum administrasi dengan hukum lainnya dapat terjadi, yakni kumulasi internal dan kumulasi eksternal. Kumulasi eksternal merupakan penerapan sanksi administrasi secara bersama-sama dengan sanksi lain, seperti sanksi pidana atau sanksi perdata. Khusus untuk sanksi perdata, pemerintah dapat menggunakannya dalam kapasitasnya sebagai badan hukum untuk mempertahankan hak-hak keperdataannya. Sanksi pidana dapat diterapkan bersamasama dengan sanksi administrasi, artinya tidak diterapkan prinsip ne bis in idem (secara harfiah, tidak dua kali mengenai hal yang sama, mengenai perkara yang sama tidak boleh disidangkan untuk kedua kalinya) dalam hukum administrasi karena antara sanksi administrasi dengan sanksi pidana ada perbedaan sifat dan tujuan.

"Pelaksanaan pemberian sanksi terhadap penyimpangan penyelenggaraan reklame di Kota Malang adalah sanksi-sanksi administrasi sudah diterapkan pada pelanggaran penyelenggaraan reklame berupa pencabutan izin reklame dan sanksi denda terhadap penyelenggarareklame yang melakukan pelanggaran izin reklame."10

Tabel 2. Pelanggaran Reklame Yang Diajukan ke Tingkat Persidangan Tahun 2018

\begin{tabular}{ccc}
\hline No & Bulan & Jumlah Kasus \\
\hline 1 & Januari & 0 \\
\hline 2 & Februari & 13 \\
\hline 3 & Maret & 1 \\
\hline 4 & April & 0 \\
\hline 5 & Mei & 1 \\
\hline 6 & Juni & 3 \\
\hline 7 & Juli & 2 \\
\hline 8 & Agustus & 4 \\
\hline 9 & September & 6 \\
\hline 10 & Oktober & 1 \\
\hline
\end{tabular}

Sumber : Satuan Polisi Pamong Praja Kota Malang, 2018, diolah.

8Ibid, hlm. 235-236

9 Ibid, hlm. 237

${ }^{10}$ wawancara dengan bapak Drs. Mochamad Yusuf. Selaku Kasi Bidang Penyidikan Satuan Polisi Pamong Praja Kota Malang 
Ada tiga perbedaan antara sanksi administrasi dengan sanksi pidana. Dalam sanksi administrasi, sasaran penerapannya ditujukan pada perbuatan, sedangkan dalam pidana ditujukan pada pelaku. Sifat sanksi administrasi adalah reparatoir condemnatoir yaitu pemulihan kembali pada keadaan semula dan memberikan hukuman, sanksi pidana bersifat condemnatoir. Prosedur sanksi administrasi dilakukan secara langsung oleh pemerintah, tanpa melalui peradilan. Prosedur penerapan sanksi pidana harus melalui proses peradilan. Adapun kumulasi internal merupakan penerapan dua atau lebih sanksi administrasi secara bersama-sama, misalnya penghentian pelayanan administrasi dan/atau pencabutan izin dan/atau pengenaan denda.

\section{Optimalisasi Pemerintah Kota Malang dalam Penertiban Terhadap Pemasangan Banner dan Reklame Ilegal Di Sepanjang Jalan Sukarno-Hatta Sampai Jalan Tlogomas.}

Pengaturan reklame memang pada dasarnya dilaksanakan dengan asas manfaat, keadilan, ketertiban dan kepastian hukum serta keserasian lingkungan. ${ }^{11}$ Dengan adanya asas-asas tersebut, maka untuk mengawal serta menjalankan aturanaturan dalam Peraturan Daerah Kota Malang Nomor 6 tahun 2006 itu, Satuan Polisi Pamong Praja Pemerintah Kota Malang merupakan pilar utama serta merupakan ujung tombak dalam penegakan setiap produk-produk hukum yang dikeluarkan Pemerintah Kota Malang yang telah sah dan berlaku. Pengaturan reklame sebenarnya juga mempunyai tujuan yakni; menjaga norma kesopanan, menjaga keindahan dan kelestarian lingkungan, mengoptimalkan pemanfaatan aset daerah untuk kepentingan masyarakat, meningkatkan pendapatan asli daerah.

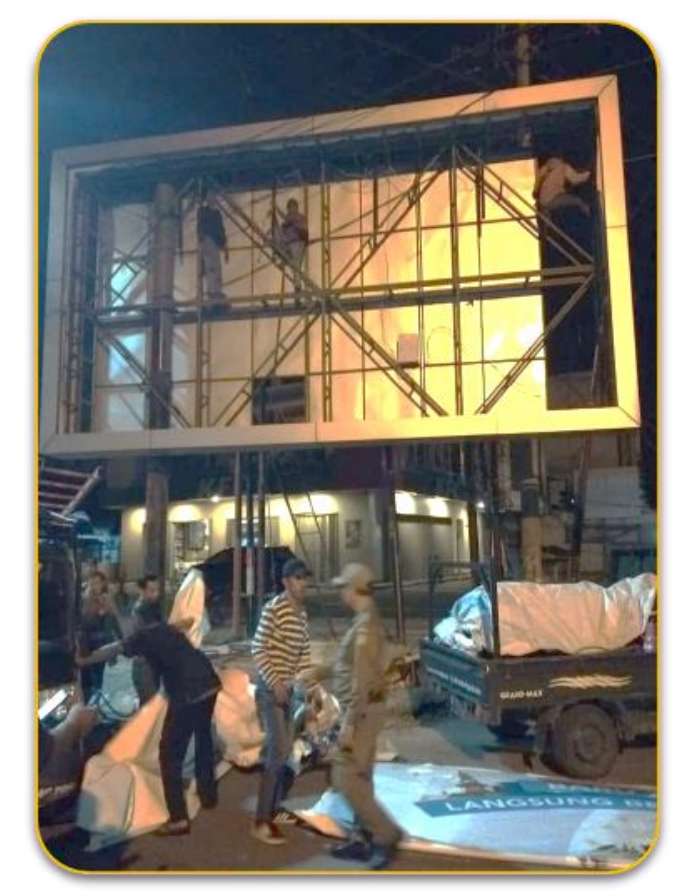

Gambar 1. Penertiban papan reklame tanpa izin (lokasi: depan ruko Sch sukarno hatta)

"Namun semua harus tetap ada penataan dengan pajak retribusi, terutama untuk menjaga estetika Kota Malang"12

\footnotetext{
11Pasal 2Peraturan Daerah Kota Malang no 4 tahun 2006, tentang Penyelenggaraan Reklame

${ }^{12}$ wawancara dengan bapak Soegianto, S.Pd. selaku Kepala Bidang Penyidikan dan Penindakan Satpol PP Kota Malang
} 
a. Upaya Dalam Mengatasi Kurangnya Jumlah Personel

Pelanggaran terhadap pemasangan reklame di sekitar jalan Sukarno-Hatta sampai jalan Tlogomas memang kerap terjadi, pada poin inilah optimalisasi kinerja Satuan Polisi Pamong Praja Pemerintah Kota Malang sangat dibutuhkan. Upaya-upaya yang dilakukan guna meningkatkan kinerja atau upaya optimalisasi kinerja Satuan Polisi Pamong Praja dalam menghadapi kendala-kendala yang dihadapi dalam permasalahan kurangnya personel Satuan Polisi Pamong Praja memang sulit terpecahkan. Hal ini disebabkan kewenangan dalam menambah atau mengurangi personel dalam suatu badan, kantor atau satuan berada ditangan pimpinan, dalam hal ini adalah Walikota Malang beserta jajarannya yang mempunyai kewenangan dalam mengangkat pegawai baru. Memang pada kendala kurangnya personel ini, Satuan Polisi Pamong Praja hanya dapat pasrah dan menunggu kebijakan dari pimpinan, permohonan penambahan personel telah diajukan beberapa kali namun sampai saat ini masih belum mendapat respon dari pihak yang berwenang atau pimpinan.

b. Upaya Dalam Mengatasi Kurangnya Peralatan Penunjang

Kendala pada kurangnya peralatan penunjang dalam upaya penertiban pelanggaran pemasangan banner dan reklame ilegal juga merupakan salah satu faktor yang dapat mengurangi efektifitas kinerja Satuan Polisi Pamong Praja Kota Malang itu sendiri. Dalam pelaksanaan penertiban terhadap reklame insidentiil atau yang mempunyai ukuran relatif tidak terlalu besar, bukanlah menjadi permasalahan bagi Satuan Polisi Pamong Praja Kota Malang. Akan tetapi, kendala sebenarnya terjadi pada pelaksanaan penertiban reklame tetap atau reklame yang memiliki ukuran besar seperti : bando jalan, display board, billboard, reklame jembatan penyebrangan orang, reklame pagar pengaman fly over (jalan layang), reklame shop panel dan lain sebagainya.

Upaya yang dilakukan oleh Satuan Polisi Pamong Praja Kota Malang dalam meningkatkan optimalisasi kinerja, terutama dalam menghadapi kendala kurangnya peralatan penunjang, sampai saat ini hanya menggunakan jasa kepada tukang las, dengan dana yang diambil dari dana operasional Satuan Polisi Pamong Praja Kota Malang itu sendiri. Dengan demikian, maka Satuan Polisi Pamong Praja Kota Malang memiliki anggaran pengeluaran rutin untuk membayar uang jasa kepada tukang las pada setiap eksekusi terhadap pelanggaran pemasangan reklame yang dilaksanakan oleh jajaran Satuan Polisi Pamong Praja Kota Malang. Hubungan kerja antara Satuan Polisi Pamong Praja Kota Malang dengan jasa tukang las adalah hubungan lepas, artinya tidak mengikat antara pihak yang satu dengan pihak yang lain. Hubungan kerja demikian hanya bersifat insidentil saja, yakni tukang las mendapat bayaran atau ongkos dari beberapa banyak reklame yang dibongkar atau ditertibkan oleh Satuan Polisi Pamong Praja Kota Malang. 


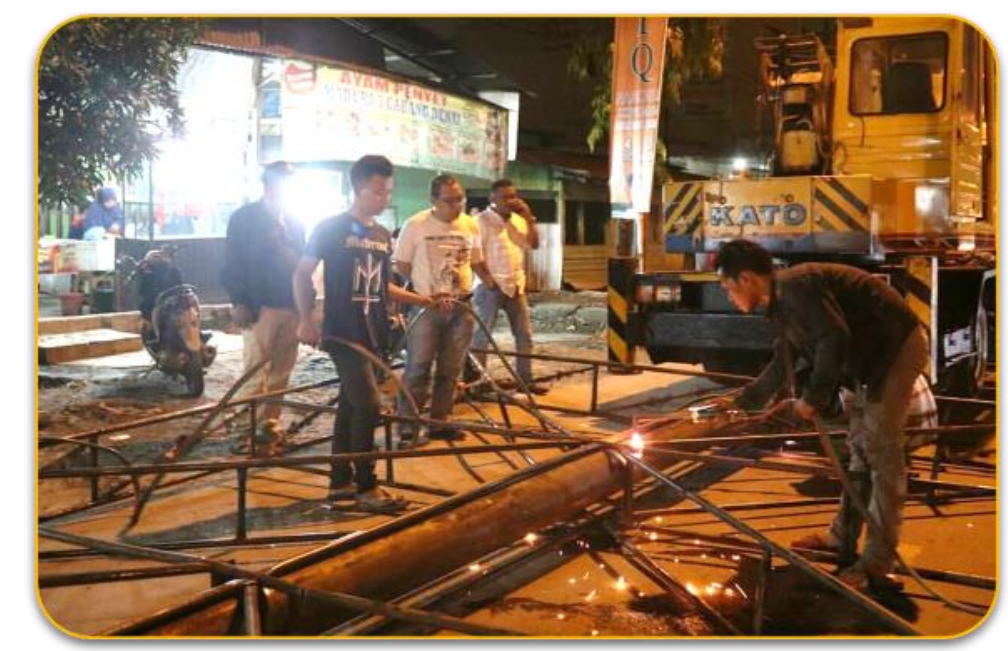

Gambar 2. Penggunaan jasa tukang las (lokasi: samping indomaret Tlogomas)

c. Upaya Dalam Mengatasi Reklame Liar Tanpa Izin

Dalam mengatasi reklame liar tanpa izin oleh Satuan Polisi Pamong Praja Pemerintah Kota Malang, saat ini hanyalah difokuskan pada penertiban yang lebih insentif, berupa penambahan frekuensi patroli per hari oleh jajaran Satuan Polisi Pamong Praja Kota Malang. Untuk pelanggaran reklame tetap atau reklame yang mempunyai ukuran besar, kasus tersebut akan diajukan ke persidangan di Pengadilan Negeri Malang. Sementara untuk reklame yang bersifat insidentiil sampai saat ini hanya sebatas pada tindakan eksekusi atau penertiban oleh Satuan Polisi Pamong Praja Kota Malang.

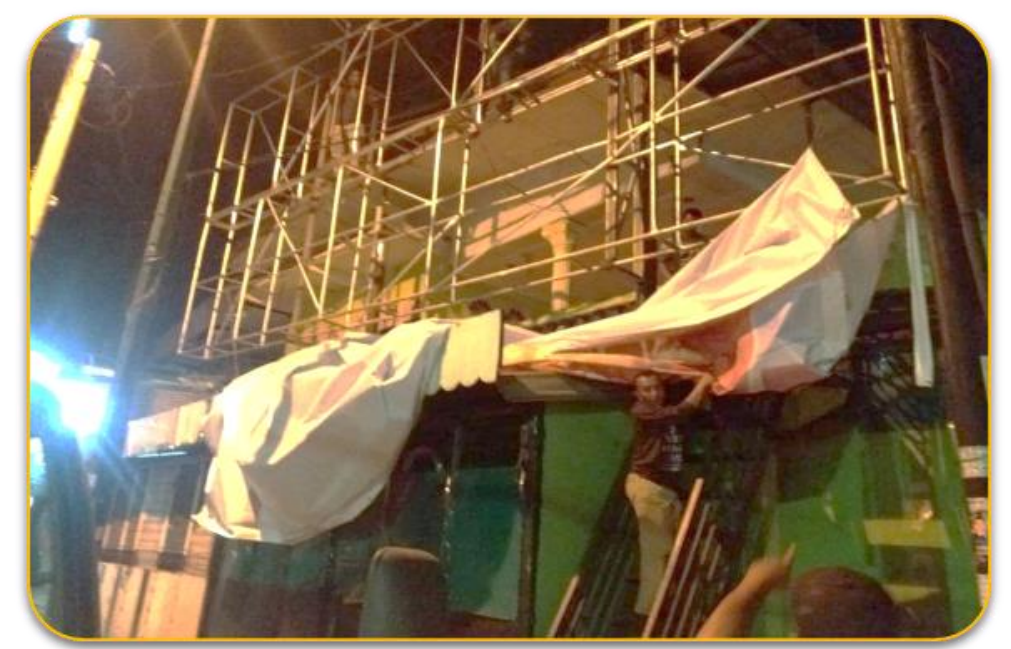

Gambar 3. Penertiban papan reklame tanpa izin (lokasi: samping ruko three second sukarno hatta)

d. Inovasi Satuan Polisi Pamong Praja Dalam Meningkatkan Optimalisasi Kinerja.

Beberapa bulan terakhir ini Satuan Polisi Pamong Praja Kota Malang berupaya mejalin hubungan kemitraan kerja dengan jasa tukang las, yakni tukang las akan dibayar setiap bulan tergantung dari berapa banyak reklame berukuran besar yang dibongkar dengan menggunakan jasa tukang las tersebut. Sehingga pengguna jasa tukang las tidak lagi dibayar per hari atau setiap selesai membongkar reklame. Kebijakan ini dipilih guna mempercepat pelaksanaan penertiban atau eksekusi 
terhadap pelanggaran pemasangan banner dan reklame tetap yang mempunyai ukuran besar. Sehingga Satuan Polisi Pamong Praja tidak perlu menunggu turunnya dana opersional terlebih dahulu setiap kali akan melakukan upaya penertiban terhadap pelanggaran pemasangan banner dan reklame tetap tersebut. Inilah langkah-langkah yang dijalankan oleh Satuan Polisi Pamong Praja Kota Malang.

Optimalisasi Pemerintah Kota Malang dalam menanggulangi banner dan reklame ilegal:

a. Razia lapangan Satpol PP Kota Malang

Razia ini bermaksud agar setiap banner dan reklame yang melanggar aturan bisa langsung di lakukan pencopotan banner dan reklame di tempat dan akan disita sebagai bahan pertanggungjawaban.

b. Penerapan sanksi secara tegas

Pemerintah Daerah Kota Malang lewat Satpol PP akan secara terus menerus memantau dengan berbagai cara agar para pemasang banner dan reklame jera. Salah satunya adalah dengan cara pencopotan banner dan reklame yang bermasalah dan pihak satpol PP akan memanggil para penanggung jawab lalu akan langsung diproses dan langsung ditindak tegas ditempat.

c. Pemantauan data yang valid

Dari tahun ke tahun, Pemerintah Kota Malang sangat terbebani dengan susahnya pengambilan data yang kurang relevan sehingga para pensurvey lapangan akan kesulitan juga menemui mana banner dan reklame yang harus ditindak tegas dan mana banner dan reklame yang hanya diberi peringatan saja.

Upaya optimalisasi Pemerintah Kota Malang dari tahun ke tahun sangat baik dan mengalami kemajuan. Tidak luput dari bantuan pihak Satpol PP yang dimana satpol PP sudah mendalami perannya sebagai pengeksekusi banner dan reklame yang ilegal. Tidak sampai disitu, para pekerja satpol PP juga bisa diandalkan dari tahun ke tahun bahkan Pemerintah Daerah Kota Malang tidak akan menutup kemungkinan untuk memberi penghargaan kepada para anggota satpol PP yang senantiasa melasanakan tugasnya dengan ikhlas demi kemajuan Kota Malang tercinta ini.

\section{KESIMPULAN}

Kepedulian lingkungan menyatakan sikap-sikap umum terhadap kualitas lingkungan yang diwujudkan dalam kesediaan diri untuk menyatakan aksi-aksi yang dapat meningkatkan dan memelihara kualitas lingkungan dalam setiap perilaku yang berhubungan dengan lingkungan. Kepedulian lingkungan tinggi jika seseorang mendukung atau memihak terhadap lingkungan.Jadi dapat ditarik kesimpulan kepedulian lingkungan adalah tingkat fokus perhatian terhadap suatu tempat dimana suatu makhluk hidup itu tumbuh yang meliputi unsur unsur penting seperti tanah, air dan udara, yang mana memiliki arti penting dalam kehidupan setiap makhluk hidup, dimana manusia berada dan mempengaruhi kelangsungan hidup serta kesejahteraan manusia dan jasad hidup lainnya, yang mencakup lingkungan hidup alami, lingkungan hidup binaan atau buatan dan lingkungan hidup budaya atau sosial.

Banyaknya pelanggaran pemasangan reklame terutama yang mempunyai ukuran besar, tentu saja akan membutuhkan dana ekstra atau dana yang lebih besar dalam melaksanakan penertiban atau pembongkaran reklame tersebut. Sangat dimungkinkan ke depan jumlah pelanggaran pemasangan reklame yang berukuran besar pun bertambah. Dana yang diperlukan dalam pembongkaran atau penertiban sebenarnya lebih banyak 
dialokasikan pada pembayaran atau ongkos kerja kepada jasa tukang las. Untuk itu, aparat Satuan Polisi Pamong Praja mempunyai kendala pada kurangnya peralatan yang memadai untuk digunakan melakukan pembongkaran dalam upaya penertiban pelanggaran reklame.

Pada penertiban pelanggaran reklame yang mempunyai ukuran besar, biasanya pihak Satuan Polisi Pamong Praja masih melaporkan kepada atasan dan baru dapat dilaksanakan pembongkaran atau eksekusi apabila dana yang dibutuhkan telah cair atau tersedia. Akan tetapi, beberapa tahun terakhir ini pihak Satuan Polisi Pamon Praja menjalin rekanan atau bermitra dengan penyedia jasa tukang las. Dengan bermitra seperti ini maka tidak perlu menunggu ketersediaan atau cairnya dana untuk pembongkaran reklame. Kemitraan ini dibayar per bulan oleh Satuan Polisi Pamong Praja guna meningkatkan efektivitas dalam penertiban yang dilaksanakan. Meskipun telah bermitra, tetap saja setiap kali Satuan Polisi Pamong Praja dalam berpatroli menemukan pelanggaran pemasangan reklame, tetap tidak dapat melakukan eksekusi atau penertiban secara langsung. Pelaksanaan penertiban baru dapat dilaksanakan beberapa hari kemudian, hal ini disebabkan oleh masih diperlukannya koordinasi dengan mitra kerja dalam bidang jasa tukang las.

Memang tidak mudah dalam melaksanakan penertiban terhadap reklame yang mempunyai ukuran besar, terutama yang lokasi reklame tersebut terletak di jalan protokol Kota Malang yang padat lalu lintas atau masyarakat. Keadaan demikian semakin terasa kurang efektif apabila ternyata terdapat lebih dari satu pelanggaran pemasangan reklame dengan ukuran yang sangat besar di waktu yang sama atau hampir bersamaan.

Pemasangan papan reklame, sebetulnya sudah ada mekanismenya, seperti papan reklame harus dipasang pada tempat yang memang tidak mengganggu kepentingan publik seperti di trotoar.Bila ada pemasangan reklame tidak pada tempatnya, kewajiban petugas Tramtib di kecamatan dan kelurahan untuk melarangnya dan mengarahkan pemasangan reklame sesuai ketentuan yang berlaku.Apabila pemasangan papan reklame tidak pada tempatnya, berdampak besar terhadap terganggunya keamanan dan kenyaman publik serta keindahan daerah. Bukan saja dilarang pasang di trotoar, konstruksi papan reklame juga harus melihat segi keamanan dan kenyamanan, jangan-jangan suatu ketika tiba-tiba reklamenya roboh hingga menimbulkan korban bagi orang lain.

Dengan demikian, diperlukan penegakan hukum agar tercapai ketertiban dan kepatuhan terhadap peraturan dalam perizinan reklame.Selain untuk pembinaan, pengaturan, pengendalian dan pengawasan serta penegakan hukum dan dampak negatif dari pemberian izin dalam rangka melindungi kepentingan umum dan menjaga kelestarian lingkungan, maka perlu dilakukan pengaturan tentang Retribusi Izin Pemasangan Reklame.Bagi Pemerintah, dalam hal ini Pemerintah Daerah, reklame merupakan salah sumber APBD, dimana pelaku usaha yang berkepentingan terhadap pemasangan iklan tersebut membayar pajak dalam jumlah tertentu untuk pemasangan reklame dalam durasi tertentu di wilayah-wilayah strategis Kabupaten/Kotamadya..

\section{SARAN}

1. Untuk menunjang Kinerja Satuan Polisi Pamong Praja beserta jajarannya, serta untuk menekan biaya operasional yang dikeluarkan guna membayar jasa tukang las dalam hal mengeksekusi reklame yang melanggar, maka Satuan Polisi Pamong Praja Kota Malang perlu memiliki peralatan yang diperlukan dalam membongkar atau melaksanakan penertiban reklame terutama reklame tetap yang memiliki ukuran besar. Selain efektif dalam segi waktu karena langsung dapat melaksanakan eksekusi, juga tidak membebani dari segi biaya mengingat reklame yang melanggar di Kota Malang cukup banyak jumlahnya. Meskipun di sisi lain Satuan Polisi Pamong Praja harus memiliki gudang 
penyimpanan serta pembekalan pelatihan dalam merawat dan menggunakan peralatan tersebut.

2. Satuan Polisi Pamong Praja Kota Malang hendaknya aktif membuka pos atau stand di beberapa titik di Kota Malang yang dianggap strategis dan membuka call center guna meningkatkan efektivitas dalam bekerja, karena tidak menutup kemungkinan masyarakat pun dapat berpartisipasi dalam hal memberikan informasi tentang keberadaan banner dan reklame yang dianggap mengganggu serta melanggar seperti apa yang tertera dalam Peraturan Daerah Kota Malang Nomor 4 Tahun 2006 Tentang Penyelenggaraan Reklame.

\section{DAFTAR RUJUKAN}

M. Irfan Islamy, 2009,Prinsip-prinsip Perumusan Kebijakan Negara, Bumi Aksara, Jakarta. Moleong, Lexy, J. 2002. Metodologi Penelitian Kualitatif. Bandung: PT. Remaja Rosada Karya.

Nugroho, Riant. 2006. Kebijakan Publik Untuk Negara-Negara Berkembang. Jakarta: PT Elex Media Komputindo.

Philipus M. Hadjon, 1996,Penegakan Hukum Administrasi dalam Pengelolaan Lingkungan Hidup, Citra Aditya Bakti, Bandung.

HR Ridwan, 2002, Hukum Administrasi Negara, UII Press, Yogyakarta 